\title{
PHYTOCHEMICAL ANALYSIS, IN VITRO ANTIOXIDANT POTENTIAL AND GAS CHROMATOGRAPHY-MASS SPECTROMETRY STUDIES OF DICRANOPTERIS LINEARIS
}

\author{
KALPANA DEVI RAJESH ${ }^{1 *}$, SUBRAMANI VASANTHA ${ }^{1}$, ANNAMALAI PANNEERSELVAM ${ }^{1}$, \\ NAKULAN VALSALA RAJESH ${ }^{2}$, NARAYANAPERUMAL JEYATHILAKAN ${ }^{3}$
}

${ }^{1}$ Department of Botany and Microbiology, A.V.V.M Sri Pushpam College (Autonomous), Bharathidasan University (Affiliated), Poondi - 613 503, Thanjavur, Tamil Nadu, India. ${ }^{2}$ Department of Wildlife Science, Veterinary University Training and Research Centre, TANUVAS, Ramanathapuram - 623 503, Tamil Nadu, India. ${ }^{3}$ Department of Veterinary Parasitology, Veterinary College and Research Institute, Orathanadu - 614 625, Thanjavur, Tamil Nadu, India. Email: kalpanafern@gmail.com

Received: 23 June 2016, Revised and Accepted: 30 June 2016

\section{ABSTRACT}

Objective: The aim of the study was to analyze qualitative and quantitative phytochemicals, evaluate in vitro antioxidant properties and determine the bioactive compounds in extracts of Dicranopteris linearis (Burm.f.) Underw. collected from Western Ghats of Kanyakumari district.

Methods: The qualitative, quantitative phytochemical, and in vitro antioxidant analysis were performed using standard procedures. The bioactive compounds were analyzed using gas chromatography-mass spectrometry (GC-MS) instrument.

Results: The qualitative phytochemical analysis studied in aqueous, acetone, chloroform, ethanol, and petroleum ether solvent extract showed acetone had strong positivity to express the 12 phytoconstituents studied except anthocyanin when compared to other solvent extracts. The quantitative phytochemistry revealed considerable amount of terpenoids $(97.0 \pm 1.15 \mathrm{mg} / \mathrm{g})$, tannins $(30.8 \pm 0.44 \mathrm{mg}$ tannic acid equivalents/gram), phenols (28.6 $\pm 0.33 \mathrm{mg}$ gallic acid equivalents/gram), and flavonoids $(8.50 \pm 0.29 \mathrm{mg}$ quercetin equivalent/g) in decreasing order of concentrations. The in vitro antioxidant activity of aqueous, ethanol, acetone, chloroform, and petroleum ether suggested that the extract of DL has prominent antioxidant prospective against various free radicals such as 2,2-diphenyl-1-picrylhydrazyl while butylated hydroxy toluene being the standard antioxidant used. The GC-MS analysis displayed the presence of 11 bioactive compounds each belonging to various categories of phytochemicals such as terpenoids, flavonoids, phenols, and fatty acid derivatives.

Conclusion: The results indicate that D. linearis (Burm.f.) Underw. present in the Western Ghats of Kanyakumari is an effective scavenger of free radicals and has the potential to be used as a natural antioxidant which is attributed to the rich presence of secondary metabolites.

Keywords: Dicranopteris linearis (Burm.f.) Underw., Phytochemistry, Antioxidant activity, Gas chromatography-mass Spectrometry.

(C) 2016 The Authors. Published by Innovare Academic Sciences Pvt Ltd. This is an open access article under the CC BY license (http://creativecommons. org/licenses/by/4. 0/) DOI: http://dx.doi.org/10.22159/ajpcr.2016.v9s2.13636

\section{INTRODUCTION}

Medicinal plants are very ancient and are true natural medicines which are useful for the treatment of different diseases. Plants are eminent source of new therapeutic agents that helps to alleviate human ailments and promote health. The noteworthy preventive and protective properties of these substances are related to their strong antioxidative, antimutagenic and anticarcinogenic potential [1]. They can be used directly or in extracted forms for the management of various ailments due to the presence of various secondary metabolites [2]. Many plants contain a variety of phytochemical property found to be significant in the fields of agriculture, human and veterinary medicine. Natural products play a dominant role in the development of novel drug leading to treatment and prevention of diseases [3]. A sufficient number of plants have been proven to be effective against ailments and massively screened for their therapeutic compounds. Pteridophyta has been known for its medicinal and therapeutic values, gaining importance in plant-based novel drug therapy. Many species of this plant division are highly ignored and are determined to have potential secondary metabolites that act against various diseases [4]. The limited knowledge of these medicinal plants for disease control and their weed habitat make these ferns to be destroyed by human. The ferns had an important role in folklore medicine and are being used as valuable sources of food and medicine for the prevention of illness and maintenance of human and animal health. Dicranopteris linearis (Burm.f.) Underw. is a terrestrial pteridophyte covered with scales or hairs. Leaves monomorphic, large, scrambling or trailing, one to many times forked. Literature study reveals that the plant possesses significant antioxidant activity with high flavonoid content [5], antimicrobial [6], gastroprotective [7], antinociceptive, anti-inflammatory and antipyretic [8], and anthelmintic [9]. The abovementioned properties of the plant could be credited to the presence of various primary and secondary metabolites in significant quantity.

Vegetables and plants consumed as food or medicines are widely accepted to provide new sources of antioxidants because of their potential biological and pharmacological activities. In recent times, research activities on antioxidants from plants sources have attracted a wide range of interest across the world. Antioxidants have great importance because they can reduce oxidative stress which could cause damage to biological molecules [10]. Various research activities on antioxidant property of Pteridophytes have been reported [11-13]. In recent years, there is an increasing trend of screening medicinal plants for bioactive compounds as a basis for further pharmacological studies. Several studies have shown that plant derived antioxidants scavenge free radicals and modulate oxidative stress. The chemistry of free radical is complicated and it caused a major limitation in the identification of free radical scavenging activity. To withstand this problem the potential antioxidant substance is tested in in vitro model and such approaches expand the scope of antioxidant activity [14]. Research on relationship between antioxidants and prevention of non-communicable disease such as cardiovascular disease, neoplastic, and diabetic condition has attain awareness in recent years. Epidemiological and in vitro studies strongly suggest that plant food containing phytochemicals with antioxidants have potent protective effects against these diseases. However, there is widespread agreement that some synthetic antioxidants such as 
butylated hydroxyanisole, butylated hydroxy toluene (BHT), and tertbutyl hydroquinone need to be replaced with natural antioxidants owing to their hazardous health risks and toxicity [15]. Therefore, it is utmost need to find out new sources of safe and economy antioxidants of natural origin. Phenolic compounds are the natural antioxidants acting such as chelating metal ions, preventing radical formation, and improving the antioxidant endogenous system. Probably the most important natural phenolics are flavonoids. Being widespread across the plant kingdom, medicinal plants have gained tremendous interest as potential therapeutic agents against a wide range of biological actions such as antibacterial, antiviral, anticancer, anti-inflammatory, and anti-allergic activities [16]. Higher plants have developed different adaptive mechanisms to reduce oxidative damage resulting from salt stress, through the biosynthesis of a cascade of antioxidants [17]. Bearing this in mind, the present work was designed to investigate the presence of secondary metabolites, in vitro antioxidant properties and identification of bioactive compounds through gas chromatographymass spectrometry (GC-MS) analysis.

\section{METHODS}

\section{Plant collection and identification}

Fresh samples of $D$. linearis (Burm.f.) Underw. were collected from Kodhayar hills, Western Ghats of Kanyakumari district and authenticated from Scott Christian College, Nagercoil, Kanyakumari District and the specimen (Voucher No SPCH/1005) preserved in A.V.V.M Sri Pushpam College, Thanjavur, India.

\section{Preparation of fern extract}

About $1 \mathrm{~g}$ of dried powder of whole plant, D. linearis (Burm.f.) Underw. was extracted with $20 \mathrm{~mL}$ ethanol 75\%, acetone, chloroform, aqueous, and petroleum ether (Merck, extra pure) for 1 minute using an ultra turax mixer $(13,000 \mathrm{rpm})$ and soaked overnight at room temperature. The sample was then filtered through Whatman No. 1 paper in a Buchner funnel and evaporated under vacuum in a rotavator at $40^{\circ} \mathrm{C}$ to a constant weight and then dissolved in respective solvents. The dissolving rate of the crude extracts was approximately $100 \%$. The solution was stored at $18^{\circ} \mathrm{C}$ until use [18].

\section{Qualitative phytochemistry}

The phytochemical screening was assessed as per standard method [19]. Phytochemical screening was performed using aqueous, acetone, chloroform, ethanol, and petroleum ether solvents to identify the major natural chemical groups such as tannins, saponins, flavonoids, phenols, terpenoids, alkaloids, glycosides, cardiac glycosides, coumarins, steroids, anthocyanin, and betacyanin.

\section{Quantification of total terpenoids}

Total terpenoid content in the leaf extracts was assessed by standard method [20]. $1 \mathrm{~g}$ of plant powder was taken separately and soaked in alcohol for $24 \mathrm{hrs}$. Then filtered, the filtrate was extracted with petroleum ether; the ether extract was treated as a total terpenoid.

\section{Quantification of total tannins}

Tannins content in the leaf extracts was estimated by following the method [21]. The sample extracts $(1 \mathrm{ml})$ were mixed with FolinCiocalteu reagent $(0.5 \mathrm{~mL})$, followed by the addition of saturated sodium carbonate $\left(\mathrm{Na}_{2} \mathrm{CO}_{3}\right)$ solution $(1 \mathrm{~mL})$ and distilled water $(8 \mathrm{~mL})$. The reaction mixture was allowed to stand for 30 minutes at room temperature. The supernatant was obtained by centrifugation and absorbance was recorded at $725 \mathrm{~nm}$ using ultraviolet visible (UV-VIS) spectrophotometer. Different concentrations of standard tannic acid were prepared, and the absorbance of various tannic acid concentrations was plotted for a standard graph. The tannin content was expressed as $\mu \mathrm{g}$ tannic acid equivalent (TAE)/g of the sample.

\section{Quantification of total phenols}

Total phenolic content (TPC) in leaf the extracts was determined by the Folin-Ciocalteu colorimetric method [22]. For the analysis, $0.5 \mathrm{ml}$ of an aliquot of the sample was added to $0.5 \mathrm{ml}$ of Folin-Ciocalteu reagent $(0.5 \mathrm{~N})$ and the contents of the flask were mixed thoroughly. Later $2.5 \mathrm{ml}$ of $\mathrm{Na}_{2} \mathrm{CO}_{3}(2 \%)$ was added, and the mixture was allowed to stand for 30 minutes after mixing. The absorbance was measured at $760 \mathrm{~nm}$ in a UV-VIS spectrophotometer. The total phenolics contents were expressed as mg gallic acid equivalents (GAE)/g extract.

\section{Quantification of total flavonoids}

Total flavonoids content in plant extracts was determined by the aluminum chloride colorimetric method [23]. $0.5 \mathrm{ml}$ of plant extracts at a concentration of $1 \mathrm{mg} / \mathrm{ml}$ was taken, and the volume was made up to $3 \mathrm{ml}$ with methanol. Then, $\left.0.1 \mathrm{ml} \mathrm{AlCl}{ }_{3} 10 \%\right), 0.1 \mathrm{ml}$ of potassium acetate, and $2.8 \mathrm{ml}$ distilled water were added sequentially. The test solution was vigorously shaken. Absorbance was recorded at $415 \mathrm{~nm}$ after 30 minutes of incubation. A standard calibration plot was generated at $415 \mathrm{~nm}$ using known concentrations of quercetin. The concentrations of flavonoid in the test samples were calculated from the calibration plot and expressed as mg quercetin equivalent $(\mathrm{QE}) / \mathrm{g}$ of sample.

\section{In vitro free radical scavenging assays}

2,2-diphenyl-1-picrylhydrazyl (DPPH) radical scavenging activity The antioxidant activities determined using DPPH (Sigma-Aldrich) is a free radical. Scavenging activity. $100 \mu \mathrm{l}$ of leaf extracts were mixed with $2.7 \mathrm{ml}$ of methanol, and then $200 \mu \mathrm{l}$ of $0.1 \%$ methanolic DPPH was added. The suspension was incubated for 30 minutes in dark condition. Initially, absorption of blank sample containing the same amount of methanol and DPPH solution was prepared and measured as a control [24]. Subsequently, at every 5 minutes interval, the absorption maxima of the solutions were measured using a UV double beam spectra scan (Chemito, India) at $517 \mathrm{~nm}$. The antioxidant activity of the sample was compared with known synthetic standard of $0.16 \%$ BHT. The experiment was carried out in triplicates. Using the belowmentioned equation, the percentage inhibition was calculated:

$\%$ Inhibition=[Abs control-Abs sample/Abs control $] \times 100$

Where Abs is absorbance.

\section{GC-MS analysis}

Based on the preliminary phytochemical results, methanolic extract of DL was chosen for the analysis of possible bioactive compounds by GC and MS technique. The trace GC ultra and DSQII model MS from Thermo Fisher Scientific Limited were engaged for analysis [25]. The instrument was set as follows, injector port temperature set to $250^{\circ} \mathrm{C}$, interface temperature set as $250^{\circ} \mathrm{C}$, and source kept at $200^{\circ} \mathrm{C}$. The oven temperature programed as a variable, $70^{\circ} \mathrm{C}$ for 2 minutes, $150^{\circ} \mathrm{Cat} 8^{\circ} \mathrm{C} /$ minutes, up to $260^{\circ} \mathrm{Cat}$ $10^{\circ} \mathrm{C} /$ minutes. Split ratio set as $1: 50$ and the injector used was splitless mode. The DB-35 MS nonpolar column was used whose dimensions were $0.25 \mathrm{~mm}$ OD $\times 0.25 \mu \mathrm{m}$ ID $\times 30 \mathrm{~m}$ length procured from Agilent Co., USA. Helium was used as the carrier gas at $1 \mathrm{ml} /$ minutes. The MS was set to scan from 50 to $650 \mathrm{Da}$. The source was maintained at $200^{\circ} \mathrm{C}$ and $<40$ motor vacuum pressure. The ionization energy was $-70 \mathrm{eV}$. The MS was also having inbuilt pre-filter which reduced the neutral particles. The data system has two inbuilt libraries for searching and matching the spectrum. NIST4 and WILEY9 each contain more than 5 million references. Only those compounds with spectral fit values equal to or $>700$ were considered positive identification.

\section{RESULTS}

\section{Qualitative phytochemistry}

Qualitative analysis indicated the presence of 12 phytoconstituents, except anthocyanin. Out of 5 solvent extracts, acetone extract performed well to show positivity of phytoconstituents than other 4 solvent extracts (Table 1).

\section{Quantitative phytochemistry}

The results of the quantitative analysis indicated the presence of significant quantities of terpenoids $(97.0 \pm 1.15 \mathrm{mg} / \mathrm{g})$, tannins 
Table 1: Qualitative phytochemistry of various solvent extract of Dicranopteris linearis (Burm. f.) Underw.

\begin{tabular}{|c|c|c|c|c|c|}
\hline Phytoconstituents & Aqueous & Acetone & Chloroform & Ethanol & Petroleum ether \\
\hline Tannins & - & ++ & - & + & - \\
\hline Saponins & ++ & + & + & + & + \\
\hline Quinones & ++ & ++ & - & ++ & - \\
\hline Terpenoids & + & ++ & - & ++ & + \\
\hline Steroids & + & ++ & + & ++ & + \\
\hline Flavonoids & ++ & ++ & - & + & - \\
\hline Phenol & ++ & ++ & + & + & + \\
\hline Glycosides & - & + & - & - & - \\
\hline Cardiac glycosides & + & + & - & + & - \\
\hline Coumarins & ++ & + & - & ++ & - \\
\hline Anthocyanin & - & - & - & - & - \\
\hline Betacyanin & + & + & - & + & - \\
\hline
\end{tabular}

+: Positive, ++: Strong positive, -: Negative

(30.8 $\pm 0.44 \mathrm{mg} \mathrm{TAE} / \mathrm{g})$, phenols $(28.6 \pm 0.33 \mathrm{mg} \mathrm{GAE} / \mathrm{g}$ ), and flavonoids (8.5 $\pm 0.29 \mathrm{mg} \mathrm{QE} / \mathrm{g}$ ) in decreasing order of concentrations (Table 2).

\section{In vitro antioxidant activities}

The DPPH free radical scavenging activity for antioxidant property showed acetone extract had strongest antioxidant potential $(96.0 \%)$, and petroleum ether extract had least activity (52.7\%) (Table 3).

\section{GC-MS analysis}

The GC-MS chromatogram and mass spectrum of methanolic extracts of D. linearis (Burm.f.) Underw. are displayed in Fig. 1. GC-MS analysis resulted in the identification of 7 chemical compounds. The retention time, molecular formula, and the area $\%$ are presented in Table 4 and the nature of compounds and medicinal uses are mentioned in Table 5.

\section{DISCUSSION}

Examination for evidence of phytoconstituents showed acetone extract performed well to express the phytochemicals in the fern studied. Tannin, phenol, terpenoid, flavonoid, quinones, and saponins showed strong positivity in acetone fern extract which was the best solvent to express phytoconstituents in this study [26] performed phytochemical screening with acetone, benzene, chloroform, ethanol, petroleum ether, and aqueous extracts of whole plants of Blechnum orientale, Ceratopteris thalictroides, Dracocephalum heterophyllum, D. linearis, Hexastylis arifolia, Inula ensifolia, Nephrolepis multiflora, Pellaea calomelanos, Partulina confusa, and leaves and rhizomes of Drynaria quercifolia revealed that the presence or absence of the phytoconstituents depends on the solvent medium used for extraction and the physiological property of individual taxa. This study on the phytochemical analysis of $D$. linearis (Burm.f.) Underw. was in confirmation with the study of Mithraja et al. [27] stated that tannin containing drugs are used in medicine as an astringent and have been found to possess antiviral, antibacterial, and anti-parasitic effects for possible therapeutic applications. Since tannin was present in the acetone and ethanolic extract of all the fern under study. Similarly [28] ascertain the presence of different Phytoconstituents in the water, methanol, ethanol and acetone extracts of 34 species of pteridophytes by qualitative screening methods and stated water and ethanol revealed maximum number of phytochemicals than methanol and acetone.

Plant-derived secondary metabolites such as alkaloids, polyphenols, saponins, tannins, terpenoids, and flavonoids are gaining much importance in recent years due to their imperative medicinal activities such as antioxidant, antitumor, antimicrobial, antidiabetic, and anthelmintic activity. The results of this study suggest that the acetone extract of D. linearis (Burm.f.) Underw. contains considerable quantities of terpenoids, tannins, phenols, and flavonoids in a decreasing order of concentrations.

GC-MS analysis showed the presence of 11 phytoconstituents belonging to varied nature of chemical compounds and possess various biological activity. Hexadecanoic acid, dioctyl ester (CAS) one of the
Table 2: Quantitative phytochemical analysis of Dicranopteris linearis (Burm. f.) Underw. extract

\begin{tabular}{ll}
\hline Parameters & Contents \\
\hline Total terpenoids (mg/g sample) & $97.00 \pm 1.15$ \\
Total tannins (mg/g of TAE) & $30.80 \pm 0.44$ \\
Total phenols (mg/g of GAE) & $28.60 \pm 0.33$ \\
Total flavonoids (mg/g of QE) & $8.50 \pm 0.29$ \\
\hline
\end{tabular}

TAE: Tannic acid equivalent, GAE: Gallic acid equivalents, QE: Quercetin equivalent

major compounds detected through GC-MS analysis is a palmitic acid derivative exhibit various biological function such as antioxidant, flavouring agent, pesticide, lubricant, antiandrogenic, haemolytic, alpha reductase inhibitor, anti-inflammatory, hypocholesterolemic, nematicide, insectifuge, and anti-bacterial activity [29]. The results of the phytochemical screening and quantitative estimation of the chemical constituents of plant sample have indicated the high content of terpenoids, total tannin, total phenol, and flavonoids. The abundance of flavonoids which are hydroxylated phenolics substances might be responsible for their therapeutic effectiveness against a wide array of micro-organisms, probably due to their ability to complex with extracellular and soluble proteins and to complex with the bacterial cell wall [30]. Flavonoids and other phenolic compounds are potent water-soluble antioxidants and free radical scavengers, which prevent oxidative cell damage, have strong anticancer activity and anthelmintic activity [31]. QUERCETIN 7,3',4'TRIMETHOXY, a potent flavonoid (polyphenolic group) present in these fern extract under GC-MS analysis might be attributed to significant antioxidant property [24]. PHYTOL, a terpenoids derivative also attribute to significant antioxidant property in D. linearis (Burm.f.) Underw. [32].

Swamy et al. [33] drawn much attention to natural antioxidant and their associations with health benefits. Plants are potential sources of natural antioxidants. They produce various antioxidant compounds to counteract reactive oxygen species to survive. Some of the antioxidant compounds, namely, flavan - 4-ol glycosides, abacopterins, huperzine A, isoquercetin, di-E-caffeoyl-mesotartaric acid, flavaspidic acid PB, flavaspidic acid $\mathrm{AB}$, flavan-3-ol, kaempferol, A-type proanthocyanidins, and afzelechin were isolated from few pteridophytes such as Abacopteris penangiana, Huperzias elago, Equisetum arvense, and Dryopteris crassirhizoma. From the previous research, it has been given that only 36 numbers of pteridophyte plants species were examined for antioxidant activity study. This paper highlights the antioxidant property of $D$. linearis (Burm.f.) Underw. which is important to this group of plants since their remedial activity against different diseases is remain incomplete. Hence, an exclusive study is essential for better understanding and exploration of the potentiality of antioxidant from pteridophytes.

Lam and Lim [34] explore new and natural sources of antioxidant among some ferns in Malaysia. 15 fern species were screened. TPC was 


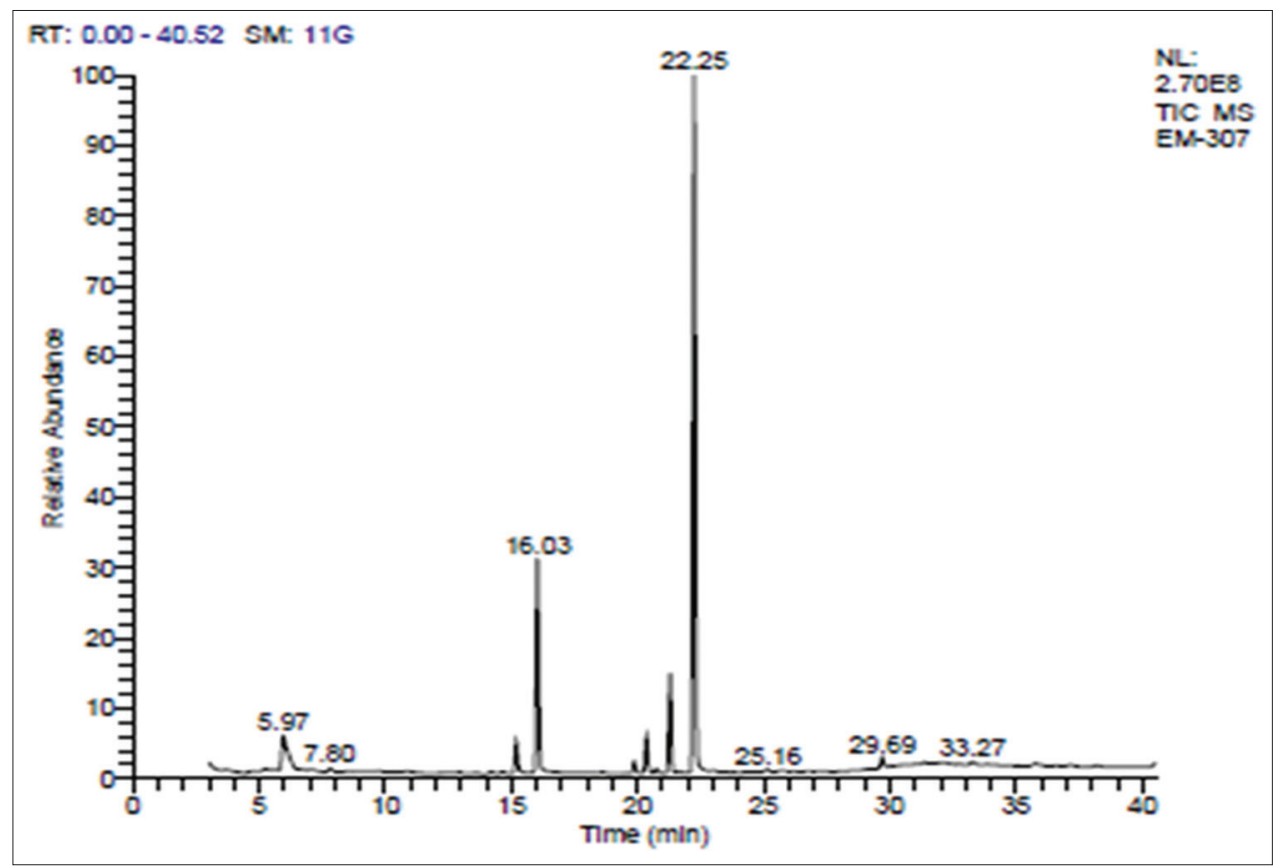

Fig. 1: Gas chromatography-mass spectrometry chromatogram of methanol extract of whole fern of Dicranopteris linearis (Burm. f.) Underw.

Table 3: DPPH free radical scavenging activity

\begin{tabular}{|c|c|c|c|c|c|c|c|}
\hline Solvent(\%) & 0 minute & 5 minutes & 10 minutes & 15 minutes & 20 minutes & 25 minutes & 30 minutes \\
\hline \multirow[t]{2}{*}{ Aqueous (OD) } & 0.11 & 0.10 & 0.10 & 0.09 & 0.09 & 0.09 & 0.09 \\
\hline & 91.3 & 92.1 & 92.1 & 92.9 & 92.9 & 92.9 & 92.9 \\
\hline \multirow[t]{2}{*}{ Acetone (OD) } & 0.13 & 0.10 & 0.09 & 0.09 & 0.07 & 0.07 & 0.05 \\
\hline & 92.1 & 92.1 & 92.9 & 92.9 & 94.4 & 94.4 & 96.0 \\
\hline \multirow[t]{2}{*}{ Chloroform (OD) } & 0.63 & 0.60 & 0.58 & 0.53 & 0.51 & 0.50 & 0.49 \\
\hline & 50.3 & 52.7 & 54.3 & 58.2 & 59.8 & 60.6 & 61.41 \\
\hline Ethanol (OD) & 0.36 & 0.17 & 0.11 & 0.09 & 0.09 & 0.08 & 0.08 \\
\hline \multirow[t]{2}{*}{ Petroleum ether (OD) } & 0.64 & 0.62 & 0.61 & 0.60 & 0.60 & 0.60 & 0.60 \\
\hline & 49.6 & 51.1 & 51.9 & 52.7 & 52.7 & 52.7 & 52.7 \\
\hline \multirow[t]{2}{*}{ BHT (OD) } & 0.14 & 0.11 & 0.09 & 0.07 & 0.06 & 0.04 & 0.02 \\
\hline & 88.9 & 91.3 & 92.9 & 94.4 & 95.2 & 96.8 & 98.4 \\
\hline Control & 1.27 & & & & & & \\
\hline
\end{tabular}

BHT: Butylated hydroxy toluene, DPPH: 2,2-diphenyl-1-picrylhydrazyl

Table 4: Secondary metabolite detected in Dicranopteris linearis (Burm. f.) Underw.

\begin{tabular}{|c|c|c|c|c|c|}
\hline No & RT & Name of the compound & Molecular formula & MW & Peak area \% \\
\hline \multirow[t]{2}{*}{1} & 5.97 & Furan (CAS) & $\mathrm{C}_{4} \mathrm{H}_{40}$ & 68 & 5.38 \\
\hline & & 5,5-dimethyl furan-2 $(5 \mathrm{H})$-one & $\mathrm{C}_{4}^{4} \mathrm{H}_{0} \mathrm{O}_{2}$ & 112 & 5.38 \\
\hline 2 & 7.80 & Dodecane & $\mathrm{C}_{12}^{6} \mathrm{H}_{26}^{2}$ & 170 & 0.45 \\
\hline \multirow[t]{2}{*}{3} & 16.03 & 1,2,3-propanetricarboxylic acid, & $\mathrm{C}_{12}^{12} \mathrm{H}_{20}^{26} \mathrm{O}_{7}$ & 276 & 16.97 \\
\hline & & $\begin{array}{l}\text { 2-hydroxy-, triethyl ester (CAS) } \\
\text { Triethyl citrate }\end{array}$ & $\mathrm{C}_{12}^{12} \mathrm{H}_{20} \mathrm{O}_{7}$ & 276 & 16.97 \\
\hline 4 & 22.25 & $\begin{array}{l}\text { 1,2-benzenedicarboxylic acid, } \\
\text { dibutyl ester (CAS) }\end{array}$ & $\mathrm{C}_{16} \mathrm{H}_{22} \mathrm{O}_{4}$ & 278 & 55.85 \\
\hline 5 & 25.16 & PHYTOL & $\mathrm{C}_{20} \mathrm{H}_{40} \mathrm{O}$ & 296 & 0.37 \\
\hline \multirow[t]{2}{*}{6} & 29.69 & QUERCETIN 7,3',4'-TRIMETHOXY & $\mathrm{C}_{18}^{20} \mathrm{H}_{16}^{40} \mathrm{O}_{7}$ & 344 & 0.20 \\
\hline & & $\begin{array}{l}\text { Hexadecanoic acid, dioctyl } \\
\text { ester (CAS) }\end{array}$ & $\mathrm{C}_{22}^{16} \mathrm{H}_{42} \mathrm{O}_{4}$ & 370 & 0.99 \\
\hline \multirow[t]{2}{*}{7} & 33.27 & 1,2-Diphenyl-5-(t-butyl) & $\mathrm{C}_{30} \mathrm{H}_{5}$ & 410 & 0.40 \\
\hline & & $\begin{array}{l}\text { acephenanthrylene } \\
\text { Fern-8-ene }\end{array}$ & $\mathrm{C}_{30}^{30} \mathrm{H}_{50}$ & 410 & 0.40 \\
\hline
\end{tabular}

measured using the Folin-Ciocalteu method. Antioxidant properties were determined via the DPPH radical scavenging, ferric reducing power (FRP), and $\beta$-carotene bleaching assays. Results showed five ferns with the very high total phenolic content of above $2000 \mathrm{mg}$ GAE/100 g fresh leaves. These ferns exhibited strong antioxidant activity based on the DPPH radical scavenging activity, FRP and 
Table 5: Activity of phytocomponents in Dicranopteris linearis (Burm. f.) Underw.

\begin{tabular}{|c|c|c|}
\hline Name of the compound & Compound nature & Biological activity \\
\hline $\begin{array}{l}\text { Furan (CAS) } \\
5,5 \text {-dimethyl } \\
\text { furan-2 }(5 \mathrm{H}) \text {-One }\end{array}$ & $\begin{array}{l}\text { Heterocyclic organic } \\
\text { compound }\end{array}$ & Antioxidant, antimicrobial \\
\hline Dodecane & Alkane & Antifungal, Antitumor \\
\hline 1,2,3-Propanetricarboxylic & Fatty acid derivative & Anti-microbial \\
\hline $\begin{array}{l}\text { acid, 2-hydroxy-, triethyl } \\
\text { ester (CAS) }\end{array}$ & Fatty acid derivative & Anti-ulcer, Anti-inflammatory \\
\hline 1,2-benzenedicarboxylic & Plasticizer compound & Antimicrobial, Anti-inflammatory, Anti-coronary activity \\
\hline acid, dibutyl ester (CAS) & \multirow[t]{2}{*}{ Fatty acid derivative } & \multirow[t]{2}{*}{ Neuro-degenerative disorder, anti-fouling, antimicrobial } \\
\hline Dibutyl Phthalate & & \\
\hline PHYTOL & Diterpene & Antimicrobial, Anticancer, Diuretic, Antioxidant, anti-inflammatory \\
\hline QUERCETIN & Flavonoids & Antioxidant, anthelmintic, antimicrobial, antileishmanial, antiplasmodial \\
\hline 7,3',4'-TRIMETHOXY & \multirow[t]{2}{*}{ Palmitic acid } & Antioxidant, flavouring agent, pesticide, lubricant, antiandrogenic, \\
\hline Hexadecanoic acid, dioctyl & & haemolytic, alpha reductase inhibitor, Anti-inflammatory, \\
\hline $\begin{array}{l}\text { 1,2-Diphenyl-5-(t-butyl) } \\
\text { acephenanthrylene }\end{array}$ & Phenol & Antioxidant, Antimicrobial \\
\hline
\end{tabular}

inhibition of lipid peroxidation. The ferns with strong antioxidant properties were Cyathea latebrosa, Cibotium barometez, Drynaria quercifolia, B. orientale, and D. linearis. In conclusion, the methanol extracts of C. latebrosa, C. barometez, D. quercifolia, B. orientale, and $D$. linearis showed very high total phenolic content are potent antioxidants which were in opinion with this study in D. linearis (Burm.f.) Underw.

Soare et al. [35] performed antioxidant analysis in methanolic extracts obtained from leaves of Athyrium filix-femina, Dryopteris affinis and Dryopteris filix-mas ferns have shown a good antioxidant activity. A positive correlation was obtained between the antioxidant activity and the total phenolic compounds. The tested ferns could be used as cosmetic ingredients, as preservatives in food or in antimicrobial therapy. Similarly, the tested D. linearis (Burm.f.) Underw. in this study could be a good antioxidant potential and is used in wound healing, anthelmintic drugs, anti-inflammatory agents, etc.

Chai et al. [36] stated promising source of phenolic antioxidants, although the effectiveness of the specific phenolic mixture in each leaf extract varied according to the type of leaf used. High contents of phenolic constituents, including anthocyanins, and high specific metal chelating activity in the edible young sterile frond of Stenochlaena palustris highlight the potential of the fern as a functional food. On the other hand, the mature sterile frond, with its high phenolic contents, potent effectiveness as reductants and year-round availability, is a potential source of phenolic antioxidants for further exploitation. Based on our findings, future studies to characterise the phenolic profiles of both young and mature sterile fronds of $D$. linearis (Burm.f.) Underw. are warranted.

Gupta et al. [37] collected eight different ferns from Mawsynram of the state of Meghalaya in India were evaluated for their in vitro antioxidant activity as well as associated phytochemical contents to explore the natural source of antioxidants. The in vitro antioxidant activity of the methanolic extract of the fern specimens was determined spectrophotometrically following DPPH, ABTS, FRP, and metal chelating methods. Other phytochemical contents such as phenol, flavonol, and orthodihydric phenol were also evaluated following standard methodology. A positive correlation between the antioxidant activities and phytochemical contents was observed. The findings suggest that all these ferns are the good source of natural antioxidants and could be used as therapeutic agents in preventing the disorders associated with oxidative stress.

\section{CONCLUSION}

In conclusion, the acetone extracts of $D$. linearis (Burm.f.) Underw. showed very high terpenoids, total phenolic, and total tannin content and are potent antioxidants. QUERCETIN 7,3',4'TRIMETHOXY, a potent flavonoid (polyphenolic group) present in these fern extract under GC-MS analysis is a strong antioxidant. The tested ferns could be used as cosmetic ingredients, as preservatives in food or in antiparasitic, antimicrobial therapy. The methods employed in this study are easily used and provide reproducible results. Much higher antioxidant activities of the acetone extracts have given evident assumption that the extracts are more potent than other solvent extracts from a medical point of view.

\section{ACKNOWLEDGMENT}

The authors acknowledge the technical support from Correspondent, Dean, Principal and Coordinator, A.V.V.M. Sri Pushpam College for the help rendered to complete the research work. The author is also thankful for the grant support from Government of Tamil Nadu, Department of Collegiate Education for the Ph. D Research Program.

\section{REFERENCES}

1. Kaur R, Arora S. Alkaloids - Important therapeutic secondary metabolites of plant origin. J Crit Rev 2015;2:1-8.

2. Pratibha P, Sophia D, Perumal PC, Gopalakrishnan VK In silico docking analysis of Emilia sanchifolia (L.) DC. Gas chromatography-mass spectrometry derived terpenoids compounds against pancreatic cancer targets (AKT and BRCA2). World J Pharm Sci 2014;3:1844-55.

3. Priyanga S, Mary MR, Hemmalakshmi S, Devaki K. Antihyperlipidemic effect of aqueous extract of Aegle marmelos and Camellia sinensis in oil fed hyperlipidemic rats. Int J Pharm Pharm Sci 2014;3:338-41.

4. Raja DP, Johnson M, Irudayaraj V, Janakiraman N. Antimicrobial efficacy of selected ferns of Western Ghats, South India. Int J Curr Pharm Res 2012;4(2):58-60.

5. Ismail NA, Shamsahal-Din NS, Mamat SS, ZabidiZ, WanZainulddin WN, Kamisan FH, et al. Effect of aqueous extract of Dicranopteris linearis leaves against paracetamol and carbon tetrachloride-induced liver toxicity in rats. Pak J Pharm Sci 2014;27(4):831-5.

6. Devi PS, Rukmini K, Indrani V, Devamma N. Antimicrobial studies and identification of cellular components of Dicranopteris linearis from Tirumala Hills. Int J Pharma Res Rev 2015;4(8):13-7.

7. Jamal H, Nurul AO, Mahmood AA, Nazia AM, Halabi MF, Salmah I. Gastro protective effects of Dicranopteris linearis leaf extract against ethanol-induced gastric mucosal injury in rats. Sci Res Essays 2012;7(18):1761-7.

8. Zakaria ZA, Ghani ZD, Nor RN, Gopalan HK, Sulaiman MR, Jais AM, et al. Antinociceptive, anti-inflammatory, and antipyretic properties of 
an aqueous extract of Dicranopteris linearis leaves in experimental animal models. J Nat Med 2008;62(2):179-87.

9. Manickam VS, Irudayaraj V. Pteridophyte Flora of the Western GhatsSouth India. New Delhi: B.J.Publications; 1992.

10. George M, Britto SJ. Phytochemical, antioxidant and antibacterial studies on the leaf extracts of Curcuma amada Roxb. Int J Curr Pharm Res 2016;8:32-8.

11. Selvaraj K, Chowdhury R, Bhattacharjee C. Isolation and structural elucidation of flavonoids from aquatic fern Azolla microphylla and evaluation of free radical scavenging activity. Int J Pharm Pharm Sci 2013;5:743-9.

12. Jinu U, Thayumanavan T, Singh TB, Sasikumar JM. In vitro antioxidant capacity of the fern, Drynaria quercifolia (L.) Sm., rhizome extract. Int J Pharm Pharm Sci 2014;6:413-6.

13. Kumar SS, Samydurai P, Ramakrishnan R, Nagarajan N. Gas chromatography and mass spectrometry analysis of bioactive constituents of Adiantum capillus-veneris L. Int J Pharm Pharm Sci 2014;6:60-3.

14. Archana D, Dixitha M, Santhy KS. Antioxidant and anti clastogenic potential of Piper longum L. Int J Appl Pharm 2015;7:11-4.

15. Safer AM, al-Nughamish AJ. Hepatotoxicity induced by the antioxidant food additive, butylated hydroxytoluene (BHT), in rats: An electron microscopical study. Histol Histopathol 1999;14(2):391-406.

16. Di Carlo G, Mascolo N, Izzo AA, Capasso F. Flavonoids: Old and new aspects of a class of natural therapeutic drugs. Life Sci 1999;65(4):337-53.

17. Falleh H, Jalleli I, Ksouri R, Boulaaba M, Guyot S, Magné C, et al. Effect of salt treatment on phenolic compounds and antioxidant activity of two Mesembryanthemum edule provenances. Plant Physiol Biochem 2012;52:1-8

18. Sreenath KB, Sundaram S, Gopalakrishnan VK, Poornima K Quantitative phytochemical analysis, in vitro antioxidant potential and gas chromatography-mass spectrometry studies in ethanolic extract of Azolla microphyla. Asian J Pharm Clin Res 2016;9(2):318-23.

19. Brinda P, Sasikala P, Purushothaman KK. Pharmacognostic studies of Merugan kizhangu. Bull Med Ethono Bot Res 1981;3:84-96.

20. Ferguson NM. A Text Book of Pharmacognosy. New Delhi: Mac Milan Company; 1956. p. 191

21. Fagbemi TN, Oshodi AA, Ipinmoroti KO. Processing effects on some antinutritional factors and In vitro multienzyme protein digestibility (IVPD) of three tropical seeds: Breadnut (Artocarpusaltilis), cashewnut (Anacardium occidentale) and fluted pumpkin (Telfairia occidentalis). Pak J Nutr 2005;4(4):250-6.

22. Slinkard K, Singleton VL. Total phenol analysis: Automation and comparison with manual methods. Am J Enol Vitic 1977;28:49-55.

23. Mervat MM, Far EI, Hanan A, Taie A. Antioxidant activities, total anthocyanins, phenolics and flavonoids contents of some sweet potato genotypes under stress of different concentrations of sucrose and sorbitol. Aust J Basic Appl Sci 2009;3(4):3609-16.

24. Lee CH, Yang L, Xu JZ, Yeung SY, Huang Y, Chen ZY. Relative antioxidant activity of soybean isoflavones and their glycosides. Food Chem 2005;90(4):735-41.

25. Geetha DH, Rajeswari M, Jayashree I. Chemical profiling of Elaeocarpus serratus L. by GC-MS. Asian Pac J Trop Biomed 2013;3(12):985-7.

26. Mithraja MJ, Marimuthu J, Mahesh M, Paul ZM, Jeeva S. Chemical diversity analysis on some selected medicinally important pteridophytes of Western Ghats, India. Asia Pac J Trop Biomed 2012;2(1):S34-S9.

27. Revathi P, Jeyaseelan ST, Thirumalaikolundhu SP. Preliminary phytochemical screening and gc-ms analysis of ethanolic extract of mangrove plant Bruguiera Cylindrica (Rhizo) 1. Int J Pharmacogn Phytochem Res 2014;6(4):729-40.

28. Mir SA, Mishra AK, Reshi ZA, Sharma MP. Preliminary phytochemical, screening of some pteridophytes from district Shopian (J \& K). Int J Pharm Pharm Sci 2013;5:632-7.

29. Cowan MM. Plant products as antimicrobial agents. Clin Microbiol Rev 1999;12(4):564-82.

30. Okwu DE. Phytochemicals and Vitamin content of indigenous spices of South Eastern Nigeria. J Sustain Agric Environ 2004;6(1):30-7.

31. Talukdar AD, Tarafdar RG, Choudhury MD, Nath D, Choudhur S. A review on pteridophyte antioxidants and their potential role in discovery of new drugs. Assam Univ J Sci Technol 2011;7(1):151-5.

32. Dr. Duke's Phytochemical and Ethnobotanical Databases. Available from: https://www.phytochem.nal.usda.gov/.

33. Swamy MK, Sinniah UR, Akhtar MS. In vitro pharmacological activities and GC-MS analysis of different solvent extracts of Lantana camara leaves collected from Tropical Region of Malaysia. Evid Based Complement Alternat Med 2015;2015:506413.

34. Lam HY, Lim YY. Antioxidant properties of some Malaysian ferns IPCBEE 2011;20:8-12.

35. Soare LC, Ferdes M, Stefanov S, Denkova Z, Nicolova R, Denev P, et al. Antioxidant activity, polyphenols content and antimicrobial activity of several native pteridophytes of Romania. Not Bot Horti Agrobo 2012;40(1):53-7.

36. Chai TT, Panirchellvum E, Ong HC, Wong FC. Phenolic contents and antioxidant properties of Stenochlaena palustris, an edible medicinal fern. Bot Stud 2012;53:439-46.

37. Gupta SK, Ghosala M, Biswas R, Biman KS, Das AP, Palash M. Evaluation of in vitro antioxidant activity of methanolic extracts of some ferns from Mawsynram of Meghalaya, India. Int J Curr Sci 2014;12:E87-97. 